\title{
INDEX FOR VOLUME 12
}

Journal of Direct, Data and Digital Marketing Practice (2011) 12, 402.

doi:10.1057/dddmp.2011.13

\section{Papers}

Death of 'last click wins': Media attribution and the expanding use of media data

Assessing pricing for a new product concept: PDA+electronic health records + real-time monitoring

Return on Ideas

An introduction to data mining and other techniques for advanced analytics

The rise of Volunteered Personal Information

e-Retail — Using home delivery as a service differentiator and strategic marketing tool

An examination of the profitability of customers acquired through price comparison sites: Implications for the UK insurance industry

Data governance - Protecting and unleashing the value of your customer data assets

The evolving data architecture of social customer relationship management

Online market research: Methods, benefits and issues — Part 1 Connected customer lifetime value: The impact of social media

Towards integrated e-marketing value creation process

\section{Opinion Pieces}

Obama: The marketing lessons

Multi-channel customer management: Delighting consumers, driving efficiency

Customer retention management in the recession

Integrating social into your business

Built in or bolt on: Why social currency is essential to social media marketing

In which contexts do different market segmentation strategies work best?

\section{Case Studies}

Everest: The IDM Business Performance Awards 2009:

Award winner campaign: Reinvigorating Everest's brand

Case Study 1 - Ogilvyone and IBM

Case Study 2 - Lida and MINI

Case Study 3 - Publicis Dialog and Zurich Financial Services

Serendipity 2's data \& insights projects for Coca-Cola

The Salvation Army: How to improve a best-of-breed donor

recruitment campaign

\section{New Technology Briefing}

Tracking online ad campaigns: A primer

\section{Book Reviews}

Googled: The End of the World As We Know

It by Ken Auletta

FastMAP/DMA Sustainability Tracking Study

Naked marketing: How the 4Ps have destroyed business and what to do instead

Consumerology

Creative B2B branding (no, really): Building a creative brand in

a business world

\section{Reviews}

Marketing analytics conference report

The changing mission of marketing data

Direct and digital marketing in practice (2nd edition)

\begin{tabular}{|c|c|c|}
\hline Author & Issue & Page \\
\hline Lee & 1 & 16 \\
\hline $\begin{array}{l}\text { Rabino, Gabay, Moskowitz } \\
\text { and Moskowitz }\end{array}$ & 1 & 27 \\
\hline Shaw & 1 & 52 \\
\hline Leventhal & 2 & 137 \\
\hline Mitchell & 2 & 154 \\
\hline Starkey & 2 & 165 \\
\hline Robertshaw & 3 & 216 \\
\hline Gregory & 3 & 230 \\
\hline $\begin{array}{l}\text { Woodcock, Broomfield, } \\
\text { Downer and Starkey }\end{array}$ & 3 & 249 \\
\hline Comley and Beaumont & 4 & 315 \\
\hline Weinberg and Berger & 4 & 328 \\
\hline Kucuk & 4 & 345 \\
\hline Pack & 1 & 2 \\
\hline $\begin{array}{l}\text { Peterson, Gröne, Kammer } \\
\text { and Kirscheneder }\end{array}$ & 1 & 10 \\
\hline Ginn, Stone and Ekinci & 2 & 115 \\
\hline Foux & 2 & 128 \\
\hline Ralphs & 3 & 211 \\
\hline Webber & 4 & 310 \\
\hline Boothby & 1 & 83 \\
\hline Fairlie & 2 & 17 \\
\hline Fairlie & 2 & 17 \\
\hline Fairlie & 2 & 177 \\
\hline Flood & 3 & 267 \\
\hline Colling & 4 & \\
\hline
\end{tabular}

Wilson and Pettijohn

Meadows-Klue

Fairlie

112

Fairlie

296

Mouncey

298

Walpole

303

Leventhal

Fairlie

Humphreys 